\title{
Ukraina i stosunki transatlantyckie
}

\section{Europa w polityce Baracka Obamy}

Jedną z charakterystycznych cech polityki amerykańskiej w okresie pierwszej kadencji Baracka Obamy na stanowisku prezydenta była marginalizacja Europy w globalnej strategii USA. Mogło to zaskoczyć tym bardziej, że gdy Obama obejmował najwyższy urząd w państwie powszechnie wiązano $\mathrm{z}$ nim nadzieję na poprawę stosunków Ameryki z Europa, tak bardzo nadwerężonych w czasach George'a W. Busha (Cantalapiedra, 2009, s. 113 i n.). Sam fakt, że w państwach europejskich przyjęto zmianę gospodarza Białego Domu z ogromnymi nadziejami, wręcz entuzjastycznie, stwarzał szansę na przezwyciężenie kryzysu we wzajemnych relacjach. Prezydent Obama już na starcie miał więc w ręku ważne atuty - sympatię i kredyt zaufania partnerów europejskich oraz ich deklarowane zainteresowanie dobrą współpracą.

Ale też administracja Obamy wyraźnie formułowała oczekiwania pod adresem Europy/Unii Europejskiej, zwłaszcza że skala problemów gospodarczych Ameryki, jaką w spuściźnie przejęto po Bushu, musiała spowodować skupienie uwagi przede wszystkim na walce $z$ recesją. Sądzono więc, że teraz Unia Europejska wykaże godną jej potencjału i pozycji aktywność na arenie międzynarodowej. Pisano, że także państwa europejskie powinny poczuć większą odpowiedzialność za sytuację w świecie, za przezwyciężanie trudności i rozwiązywanie problemów, co oznaczać będzie większe ich zobowiązania i powinności. Dowodzono, że kontynent europejski - chcąc zrealizować swe polityczne ambicje, ale też utrzymać dobre stosunki ze Stanami Zjednoczonymi - będzie musiał odpowiedzieć na te oczekiwania, zwiększając swe zaangażowanie na różnych polach i w różnym charakterze. Zabraknie alibi w postaci czasami aroganckiej i unilateralnej polityki poprzedniego prezydenta. „Bush pozwolił im [Europejczykom - przyp. J.K.] obarczać amerykański unilateralizm odpowiedzialnością za przejawiany przez nich brak inicjatywy i wykorzystywać błędy amerykańskiej dyplomacji jako wytłumaczenie dla własnego nicnierobienia" - pisała Anne Applebaum. Teraz jednak - zdaniem amerykańskiej publicystki - „wybiła godzina Europy” (Applebaum, 2008).

Susan Rice, wówczas główny doradca Obamy ds. zagranicznych, zapowiadała: „Polityka zagraniczna Obamy będzie oznaczać, że USA robią swoją część zadań, ale Europa też musi zrobić swoją. W dobrym partnerstwie nie ma pasażerów na gapę" (Rice, 2008). W podobnym tonie wypowiadał się Zbigniew Brzeziński: „Jeśli Europejczycy nie będą w stanie ustalić wspólnej europejskiej polityki zagranicznej, to oczywiście nie będzie prawdziwego dialogu transatlantyckiego, będzie co najwyżej dialog dwustronny między poszczególnymi krajami. Jeśli Europa chce mieć odpowiednią rangę w świecie, musi mówić jednym głosem" (Brzeziński, 2008). Także sam prezydent 
Obama stawiał sprawę jasno: „Chcemy mieć silnych sojuszników. Nie chcemy być patronami Europy. Oczekujemy, że będziemy partnerami Europy".

Zresztą czarnoskóry prezydent Stanów Zjednoczonych, pozbawiony tych tradycyjnych więzi emocjonalnych z Europa, jakie łączyły poprzednich gospodarzy Białego Domu ze Starym Kontynentem, postrzegał go przede wszystkim w kontekście i w zestawieniu $z$ innymi problemami, stanowiącymi na początku jego prezydentury rzeczywiste wyzwanie dla amerykańskich interesów i określających amerykańskie priorytety. Stabilna Europa zdawała się nie być już głównym zobowiązaniem Stanów Zjednoczonych w zakresie bezpieczeństwa i dlatego została podporządkowana innym celom amerykańskiej polityki zagranicznej. Myśl tę rozwijał Robert Kagan, pisząc, że „Obama jest pierwszym naprawdę pozimnowojennym prezydentem USA. Nie łączy on wielkich emocji z Europą. [...] Jako człowiek sterujący supermocarstwem, które ma wiele kłopotów, zastanawia się przede wszystkim nad tym, co Europa może zrobić dla niego. A jej znaczenie strategiczne maleje z roku na rok - na jej własną prośbę, z powodu tego, co Europa robi i nie robi" (Kagan, 2010).

Zatem o bliskich związkach ze Starym Światem decydować miały teraz bardziej względy pragmatyczne, a nie - jak to było przez ponad pół wieku - związki historyczne, emocjonalne lub kulturowe. Relacje Stany Zjednoczone-Europa nie miały być tylko wspólnotą wartości i zasad, sprowadzającą się do problemu bezpieczeństwa, czyli de facto NATO, ale winny zyskać bardziej praktyczny charakter. Ameryka czasu Obamy zdecydowanie chciała Unii Europejskiej, na którą będzie można liczyć przy rozwiązywaniu różnych problemów i która będzie angażować się na miarę swych możliwości w różnych częściach świata, nawet tych odległych od teatru europejskiego. Wobec różnych wyzwań, takich jak problemy globalnej gospodarki, zwłaszcza w erze głębokiego kryzysu, międzynarodowy terroryzm, groźba proliferacji broni jądrowej, konflikt bliskowschodni, celem administracji Obamy była współpraca z każdym, kto okazałby skuteczną pomoc przy rozwiązaniu tych zadań. W tym nowy gospodarz Białego Domu widział szczególną rolę sojuszników europejskich (Obama, 2011). W efekcie miało to oznaczać zrównoważenie wzajemnych relacji i nowy podział obowiązków.

Pytanie zasadnicze brzmiało, czy Europa takie wyzwanie podjęła. Wprawdzie w wypowiedziach przedstawicieli Unii Europejskiej na początku wiele było deklaracji i woli współdziałania z nowym prezydentem. Ówczesny przewodniczący Parlamentu Europejskiego Hans-Gert Pöttering w marcu 2009 r., podczas spotkania z sekretarz stanu Hillary Clinton, apelował o wspólne działanie jako równorzędni partnerzy „w budowaniu lepszego świata" (Pöttering, 2009). Chodziło zresztą nie tylko o współprace w zakresie bezpieczeństwa i polityki, ale przede wszystkim wspólne wysiłki na rzecz przezwyciężenia kryzysu gospodarczego. Na tej podstawie pojawiła się nadmiernie optymistyczna konstatacja, że „ten światowy kryzys finansowy może okazać się początkiem nowego partnerstwa transatlantyckiego" (Hasselbach, 2009).

Taki był początek, jednak generalny bilans w relacjach amerykańsko-europejskich po pierwszych czterech latach obecności Obamy w Białym Domu trudno było uznać za dodatni. Z perspektywy amerykańskiej to Europa nie spełniła pokładanych w niej nadziei. Państwa europejskie, choć coraz bardziej zintegrowane w Unii Europejskiej, posiadającej już swego rodzaju ministra spraw zagranicznych, nie zdołały zaprezentować się jeszcze jako zdeterminowany i skuteczny gracz na arenie międzynarodowej, mówiący 
jednym, silnym głosem. Doświadczył tego zresztą osobiście prezydent Obama już w kwietniu 2009 r., podczas swego pierwszego pobytu w Europie, gdy w trakcie spotkania z przywódcami państw członkowskich UE w Pradze był zmuszony wysłuchiwać różnych, czasami sprzecznych ze sobą głosów polityków europejskich, a zabrakło jasnego przekazu, co Europa może wspólnie zrobić i jak może działać. Efektem tego rozczarowania było odwołanie przez prezydenta Obamę udziału w kolejnym szczycie USA-UE, planowanym na maj $2010 \mathrm{r}$. w Hiszpanii, co uznano w Europie za przykry gest ze strony amerykańskiego prezydenta. Amerykanie zaś w kuluarowych rozmowach informowali, że szczyty Unii Europejskiej są stratą czasu, a prezydent jako człowiek praktyczny bardzo ceni sobie czas (EU-US, 2010) ${ }^{1}$. Wprawdzie z czasem incydent ów zyskał znacznie mniejsze znaczenie, niż początkowo mu przypisywano, ale niemiłe wrażenie pozostało.

Jakkolwiek zachowanie prezydenta Obamy mogło być przykre dla Starego Świata, to jednak trudno było zaprzeczyć, że Europejczycy nie przyjęli w relacjach międzynarodowych roli ważnego podmiotu, którym Unia Europejska przecież była i co zapisano w traktacie lizbońskim. Co gorsze, mimo upływu czasu ten deficyt europejskiej dyplomacji zdawał się nie ustępować. Brak było aktywności Unii Europejskiej w odniesieniu do konfliktu bliskowschodniego, gdzie zabrakło rzeczywistej determinacji, aby zaangażować się dyplomatycznie na miarę możliwości Wspólnej Europy w ożywienie i realizację procesu pokojowego (na spotkaniu w Waszyngtonie, inaugurującym nowy etap rozmów izraelsko-palestyńskich, w lecie 2010 r., nie było żadnego przedstawiciela z Brukseli). Unia Europejska, oczekując na działania Stanów Zjednoczonych, w praktyce ograniczała swą rolę do pomocy finansowej dla strony palestyńskiej (około 1 mld euro rocznie). Natomiast wobec Izraela i jego polityki państwa UE demonstrowały różne stanowiska i oceny - od bardzo krytycznych (dominujących np. w Wielkiej Brytanii i Francji) do bardziej przychylnych (wyrażanych np. w Polsce). Podobnie słabo dostrzegalna była rola UE przy rozwiązywaniu groźnego i nadal nieprzezwyciężonego dylematu ambicji nuklearnych Iranu. A przecież o pomoc w tej sprawie i przygotowanie konkretnych propozycji już na początku swej prezydentury Obama apelował do sojuszników europejskich. Było to zrozumiałe, gdyż - jak wiadomo - swego czasu to państwa tzw. trojki (Francja, Niemcy, Wielka Brytania) występowały jako strona w rozmowach z reżimem ajatollahów. Odpowiedzi z Europy jednak nie było.

Nie istniała więc zdefiniowana wspólna europejska polityka zagraniczna wobec najważniejszych dla świata spraw. Nadal zależała ona przede wszystkim od woli politycznej demokratycznie wybieranych rządów, a właściwie od zdania głównych przywódców Europy: kanclerza Niemiec, prezydenta Francji lub premiera Wielkiej Brytanii. Choćby podczas ,arabskiej wiosny” w 2011 r., gdy to strategia wobec Libii wypracowana została przez USA oraz tandem francusko-brytyjski, poza strukturami Unii Europejskiej. Przygotowując zbrojną interwencję, amerykańska sekretarz stanu Clinton kontaktowała się głównie z szefami dyplomacji Francji i Wielkiej Brytanii, a nie wysokimi urzędnikami $U^{2}$. Sama lady Catherine Ashton, która jako pierwsza

\footnotetext{
1 Zdecydowano wobec tego, że szczyty USA-UE odbywać się będą nie co roku, jak było to w zwyczaju, ale w razie konieczności i gdy pojawią się konkretne sprawy do rozstrzygnięcia.

2 Przyznawal to w rozmowie z polskim dziennikarzem prof. Andrew A. Michta, amerykański ekspert ds. bezpieczeństwa i wspólpracy transatlantyckiej: „Odpowiedzmy sobie na pytanie: kto ma
} 
kierowała Europejską Służbą Działań Zewnętrznych, zdawała się nie posiadać na tyle silnego mandatu i autorytetu oraz wystarczającej determinacji, aby kształtować i forsować wspólny unijny punkt widzenia. A przecież można było sądzić, że traktat lizboński wyposaży UE w narzędzia, które będzie można wykorzystać w takich przypadkach jak Libia, a wcześniej Egipt czy Tunezja, aby zintegrować państwa członkowskie wobec ważnego zadania z zakresu polityki zagranicznej i bezpieczeństwa. Tymczasem tej konsolidacji zabrakło i w rozpoczętej 19 marca 2011 r. operacji wojskowej w Libii nie wszystkie państwa członkowskie Unii Europejskiej wzięy udział, zabrakło m.in. Niemiec, Holandii i Polski (Kiwerska, 2003a, s. 37 i n.). Choćby dlatego akcja ta nie miała charakteru wspólnego działania Stanów Zjednoczonych i Unii Europejskiej, a jedynie była operacją niektórych państw europejskich i USA.

Nawet kolejne placówki dyplomatyczne UE, otwierane w różnych państwach Azji, Afryki i obu Ameryk, nie rozwiązywały problemu - ani nie potwierdzały istnienia jednolitej polityki zagranicznej Unii Europejskiej, ani nie czyniły z Brukseli liczącego się dla USA partnera w sprawach międzynarodowych. Można było zatem powiedzieć, że potrzeba jeszcze czasu i niesłabnącego zapału, aby udało się wykorzystać istniejący potencjał i wspólnym wysiłkiem stworzyć jednolitą politykę europejską, przynajmniej w odniesieniu do niektórych międzynarodowych kwestii i problemów.

Rangę Unii Europejskiej podważały też krytycznie oceniane w Stanach Zjednoczonych próby Europy przezwyciężenia kryzysu gospodarczego i załamania finansowego w strefie euro. Dezawuowało to wcześniejsze prognozy, że kryzys stanie się czynnikiem wzmacniającym wspólnotę transatlantycką. Teraz podkreślano brak wyraźnego przywództwa na kontynencie europejskim, które zdecydowanie i skutecznie podjełoby to największe od recesji końca lat dwudziestych ubiegłego stulecia wyzwanie gospodarcze. Zresztą można wskazać na wzajemne oskarżanie się Stanów Zjednoczonych i UE o lekceważenie powagi sytuacji kryzysowej i nieadekwatny sposób przezwyciężenia problemów ekonomicznych (pobudzanie gospodarki poprzez dopływ środków stosowane w USA, a na gruncie europejskim - forsowanie cięć budżetowych w strefie euro) (Götz, 2013, s. 192-201).

Wracając do przywództwa w Europie, to administracja Obamy oczekiwała, że to właśnie Niemcy z racji swego potencjału i rangi na kontynencie staną się inicjatorem i motorem rosnącej aktywności Unii Europejskiej, a przede wszystkim odegrają główną rolę w walce $\mathrm{z}$ kryzysem gospodarczym. To od determinacji i skuteczności kanclerz Angeli Merkel miało zależeć - zdaniem Waszyngtonu - czy Europa upora się z załamaniem gospodarczym, czy nie. Niektórzy amerykańscy analitycy pisali wręcz, że Niemcom dzisiaj, w drugiej dekadzie XXI wieku, przypadła w Europie taka rola w wymiarze gospodarczym, jaką w ubiegłym stuleciu odgrywały Stany Zjednoczone. Jakkolwiek trudno nie docenić roli niemieckiej kanclerz w walce z kryzysem, to jednak z perspektywy amerykańskiej nie były to działania na miarę realnych potrzeb i powszechnych oczekiwań (Riester, 2009, s. 2; Kiwerska, 2011, s. 262-263).

więcej do powiedzenia, szefowa dyplomacji UE czy np. szef francuskiego MSZ? Pozycja instytucji europejskich zależy od tego, jaka siła za nim stoi. [...] Gdy trzeba podejmować trudne decyzje, dzwonimy do tych, którzy są w stanie to zrobić, czyli do szefów poszczególnych państw" (Michta, 2011). 
To, że Unia Europejska nie sprawdzała się jako strategiczny aktor, na którego liczyły Stany Zjednoczone, wynikało - obok całego kompleksu jej problemów związanych z kryzysem gospodarczym, a także pewnej asymetrii istniejącej między państwami członkowskimi UE - przede wszystkim z braku gotowości państw europejskich do podejmowania większych zobowiązań i większej odpowiedzialności za bieg spraw w świecie. Wymagało to bowiem pokonania narodowych egoizmów, wykazania większego poświęcenia, zwrócenia uwagi na sprawy nie zawsze pierwszorzędne z narodowego punktu widzenia, wreszcie zademonstrowania woli partnerskiego współdziałania ze Stanami Zjednoczonymi. Tymczasem tych przesłanek na ogół brakowało. Unia Europejska nadal nie potrafiła wykreować własnego przywództwa politycznego, ani uzgodnić, jaką rolę powinna odgrywać w świecie (Brzeziński, 2010, s. 28). Brak było nawet zgodności wśród państw członkowskich czy takie wyraziste przywództwo polityczne jest Unii Europejskiej potrzebne, czy nie grozi to dominacją jednych nad drugimi, prowadzac do wewnętrznych sporów i w efekcie dekompozycji UE. Tymczasem z amerykańskiej perspektywy takie przywództwo było wręcz pożądane, gdyż ułatwiało komunikację $\mathrm{i}$ - jak zakładano w Waszyngtonie - będzie mobilizowało do skutecznego działania.

Warto dodać, że na polu polityki zagranicznej, a także w zakresie bezpieczeństwa państwa członkowskie UE zachowały silne poczucie narodowej niezależności, co w wielu wypadkach było zrozumiałe. Wszak Unię Europejską tworzą suwerenne państwa o różnych interesach, a przynajmniej różnie je często definiujące. Trudno zatem było i nadal trudno jest forsować jeden europejski punkt widzenia (Kirchner, Sperling, 2007, s. 221). Nawet angażując się w działania NATO w Afganistanie, państwa europejskie - rzecz warta przypomnienia - czynity to de facto jako indywidualni sojusznicy, silnie uzależnieni od narodowych interesów i wewnętrznych ograniczeń. Dlatego Obama, podobnie jak wcześniej Bush, miał ogromne trudności, aby przekonać europejskich sojuszników do zwiększenia liczebności ich kontyngentów operujących w ramach afgańskiej misji NATO. W efekcie Afganistan przyczynił się do nasilenia wzajemnego transatlantyckiego rozczarowania, a Europa - w ocenie Stanów Zjednoczonych - nie sprawdziła się jako zaangażowany i odpowiedzialny partner, którego Amerykanie wyraźnie potrzebowali. Partner dysponujący wspólnym, jednoznacznym stanowiskiem (Kupchan, 2009; Kiwerska, 2013b, s. 346-349).

Administracja Obamy liczyła na powstanie mocno zintegrowanej i bardziej skutecznej Europy, ale się rozczarowała. Okoliczności wymusiły więc, że zdecydowała się sprowadzić partnerstwo atlantyckie - podobnie jak było to wielokrotnie w przeszłości - właściwie do bilateralnych relacji z trzema głównymi państwami europejskimi, mającymi znaczenie i pozycję w świecie: Wielką Brytanią, Niemcami i Francją. Te kraje prezydent Obama najczęściej odwiedzał podczas swych nielicznych w czasie pierwszej kadencji podróży do Europy. Jedynie tylko one spośród państw europejskich zostały wymienione z nazwy jako najbliżsi sojusznicy Ameryki w National Security Strategy, ogłoszonej w maju 2010 r. (National, 2010) ${ }^{3}$. Ale nawet w odniesieniu do tych

3 Należy dodać, że wprawdzie w dokumencie autorzy piszą o relacjach z sojusznikami europejskimi jako o „kamieniu węgielnym zaangażowania USA w świecie i katalizatorze działań międzynarodowych", to jednak Europie poświęcono niemal tyle samo miejsca co wspólpracy z sojusznikami w Azji i Ameryce Pólnocnej. 
krajów trudno było mówić o umocnieniu więzi. „Korzyści z takiego dialogu były ograniczone politycznymi różnicami, występującymi między przywódcami tych państw" - pisał Brzeziński, powtarzając zresztą tezę, którą stawiał już znacznie wcześniej. „Dlatego - dowodził - powstanie faktycznie zjednoczonej Europy i dzięki temu liczącej się w kalkulacjach Obamy, wydaje się w najbliższym czasie niemożliwe" (Brzeziński, 2010, s. 28).

Można zatem uznać, że administracja Obamy miała powody, aby czuć się rozczarowana partnerstwem z Europa. A ponieważ przyszło jej działać w świecie nowych, konkurencyjnych wobec USA potęg, bezpośrednio zagrażających amerykańskim interesom i wyznaczających kolejne bieguny układu międzynarodowego, musiało to skutkować realnymi faktami, wręcz niekorzystnymi dla Europy i stosunków amerykańsko-europejskich. Podczas gdy Unia Europejska, ogarnięta kryzysem gospodarczym i finansowym, stojąca przed realną - jak się wówczas wydawało - perspektywą dezintegracji, przestała być owym ,natchnieniem świata", o którym pisano wcześniej (Khanna, 2009; 2011, s. 23), słabiej też rysowała się jako gospodarczy konkurent USA, a przede wszystkim nie spełniła oczekiwań Ameryki jako aktywny i skuteczny gracz na arenie międzynarodowej, to inne siły stanowily rzeczywisty problem dla Stanów Zjednoczonych. To one skupiły zainteresowanie Ameryki.

Takim wyzwaniem dla amerykańskich interesów gospodarczych i politycznych stały się Chiny, konsekwentnie i dynamicznie rozwijające się przez ostatnie lata. Co więcej, rosnący potencjał gospodarczy Chin zaowocował nasileniem ich aspiracji politycznych w regionie azjatyckim (Kagan, 2012). Pekin okazał się coraz bardziej ofensywny w stosunku do swych sąsiadów, budząc zaniepokojenie leżących w rejonie dalekowschodnim państw, w tym Japonii, a nawet Australii. Jeśli do tego dodać możliwości Chin wpływania na polityków Korei Płn., straszących świat konsekwentnie realizowanym programem nuklearnym, to nie dziwi fakt, że uwaga administracji Obamy w pewnym momencie wyraźnie skoncentrowała się na regionie dalekowschodnim (Indyk, Lieberthal, O'Hanlon, 2012, s. 24 i n.).

W listopadzie 2011 r., podczas podróży po krajach regionu Pacyfiku prezydent Obama zadeklarował: „Priorytetem USA w polityce zagranicznej stanie się region Azji i Pacyfiku". Występując przed australijskim parlamentem podkreślał, że Stany Zjednoczone jako mocarstwo Pacyfiku powinny przyczynić się do kształtowania przyszłości tego regionu. Dlatego obecność USA w rejonie Azji i Pacyfiku miała uzyskać najwyższy priorytet w amerykańskiej polityce zagranicznej (Remarks, 2011). Zaczęto wręcz mówić o amerykańskim ,zwrocie ku Pacyfikowi” (pivot to the Pacific Rim) (Indyk, Lieberthal, O'Hanlon, 2012, s. 56-59) ${ }^{4}$. Można dodać, że działo się tak kosztem Europy i europejskich sojuszników. W tym samym bowiem czasie - jesienią $2011 \mathrm{r}$. - gdy administracja Obamy ogłosiła plan drastycznych cięć w wydatkach na obronę oraz redukcję amerykańskiej obecności wojskowej w Europie, to równocześnie podpisała z premierem Australii porozumienie o wzmocnieniu amerykańskiej obecności wojskowej na antypodach.

4 Po raz pierwszy określenia tego użyło biuro prasowe Białego Domu tuż przed wizytą prezydenta Obamy w państwach Azji Południowo-Wschodniej w listopadzie 2011 r. 
Amerykański ,zwrot ku Pacyfikowi” wywołał żywą reakcję w Europie. W zasadzie uznano go za fakt przesądzony i jedynie niektórzy analitycy odważyli się twierdzić, że Europa mimo wszystko nadal pozostaje najważniejszym zobowiązaniem Stanów Zjednoczonych w zakresie bezpieczeństwa, a układ transatlantycki czynnikiem rangi i znaczenia obu jego członów. Natomiast za Atlantykiem przeważały opinie, które dość dosadnie wyraził Richard N. Haass, szef nowojorskiego Council on Foreign Relations. Dowodził on, że rola Europy w świecie będzie drastycznie spadać. „Konkluzje dla Ameryki są banalne. Choćbyśmy bardzo się starali, nie zmusimy Europejczyków, żeby spełnili nasze oczekiwania. [...] Czas poszukać nowych, równorzędnych partnerów w Azji, gdzie przenosi się środek ciężkości świata" (Haass, 2011). W ówczesnych realiach stawianie tak zdecydowanej tezy o spadajacych notowaniach Unii Europejskiej w amerykańskich kalkulacjach wydawało się jak najbardziej dopuszczalne i uzasadnione. Jakkolwiek dynamika wydarzeń międzynarodowych oraz szybko zmieniające się uwarunkowania zmuszały do ostrożności w prognozach. Nie należało niczego przesądzać.

Jednak, bilansując politykę amerykańską wobec Europy w okresie pierwszej kadencji Obamy, to z jednej strony mieliśmy poczucie jej marginalizacji w globalnej strategii USA, czego wyrazem był głośny ,zwrot ku Pacyfikowi”, z drugiej zaś - utrzymująca się inercję Unii Europejskiej w odniesieniu do wielu wyzwań i problemów, rozczarowującą dla administracji Obamy. W amerykańskiej ocenie Europa nie zaprezentowała się jako gotowy do działania, aktywny i skuteczny aktor na scenie międzynarodowej, choć zdawało się, że ma ku temu odpowiednie możliwości i narzędzia. Nasiliło się więc wrażenie dalszego, wzajemnego oddalania się Unii Europejskiej i Stanów Zjednoczonych.

\section{2. „Odwrót” ku Europie}

I początkowo nic nie wskazywało na to, że kolejne cztery lata prezydenta Obamy w Białym Domu odwrócą ten trend. Zwłaszcza po ujawnionych w maju 2013 r. rewelacjach o inwigilowaniu przez amerykańskie służby wielu przywódców zaprzyjaźnionych państw europejskich, w tym kanclerz Niemiec i polityków francuskich. $Z$ informacji przekazanych przez Edwarda Snowdena, byłego administratora systemów komputerowych amerykańskiej Agencji Bezpieczeństwa Narodowego, wynikało, że szpiegowano także unijne instytucje oraz ambasady. Reakcja w państwa Unii Europejskiej była bardzo ostra: „Podsłuchiwanie przyjaciół jest nie do zaakceptowania” - mówił rzecznik niemieckiego rządu, zaś francuski prezydent François Hollande grzmiał: „Nie możemy zaakceptować tego typu zachowania między partnerami i sojusznikami. Żądamy, by natychmiast się to skończyło". Komentarze prasy europejskiej, a także wypowiedzi niektórych polityków europejskich wręcz sugerowały, że w tej sytuacji bliska współpraca USA z Europą pozostaje pod dużym znakiem zapytania.

Obawiano się, że skandal wywołany informacjami zbiegłego do Rosji pracownika amerykańskiego wywiadu może zaszkodzić negocjacjom Stanów Zjednoczonych z Unią Europejską w sprawie umowy o wolnym handlu i inwestycjach (TTIP). Jakkolwiek by oceniać - z amerykańskiej perspektywy - rolę i znaczenie Unii Europejskiej, to jednak rozmowy na temat strefy wolnego handlu, czyli utworzenia ogromnego rynku 
transatlantyckiego automatycznie potwierdzały ekonomiczną rangę struktury brukselskiej. Co więcej, powodzenie negocjacji służyłoby nie tylko utrwaleniu w światowym handlu zachodnich regulacji i zasad, ale przede wszystkim umocnieniu współpracy między USA a UE. Tym bardziej że oba te człony wytwarzały w 2014 r. łącznie ponad 33 proc. światowego PKB, a znaczna część międzynarodowej wymiany handlowej dokonywała się między USA a UE. Natomiast zastopowanie rozmów o TTIP, co sugerowali w reakcji na rewelacje Snowdena niektórzy wysocy urzędnicy z Brukseli, oznaczałoby pogłębienie rozdźwięku na linii Stany Zjednoczone-Unia Europejska. Do pewnego momentu takie obawy wydawały się zupełnie uzasadnione. Mogło się zdawać, że relacje między Stanami Zjednoczonymi a Unią Europejskąznalazły się ponownie w stadium kryzysowym, a w sferze negocjacji nad TTIP wręcz uległy zamrożeniu.

Tymczasem wczesną wiosną 2014 r. dynamika wydarzeń na scenie międzynarodowej dość wyraźnie zmieniła trend stosunków amerykańsko-europejskich. Okazało się, że pod wpływem nowych okoliczności niektóre prognozy i oceny muszą ulec zmianie, a przynajmniej ponownej weryfikacji. $Z$ pewnością nastapiło zahamowanie marginalizacji Europy w strategii amerykańskiej. Można było wręcz odnieść wrażenie, że odbudowuje się ścisły sojusz Europy z Ameryką. Niemal jak w czasach zimnowojennych Stany Zjednoczone powracają do roli gwaranta bezpieczeństwa europejskiego.

Impulsem, zmieniającym na pewien czas niekorzystną atmosferę w relacjach Ameryki z Europą, stały się wydarzenia na Ukrainie, wywołane eskalacją imperialnych ambicji Rosji. Aneksja Krymu na przełomie lutego i marca 2014 r., stanowiąca jawne pogwałcenie suwerenności niepodległego państwa, a następnie inspirowanie i wspieranie przez Moskwę krwawej rebelii we wschodniej części Ukrainy, grożącej rozpadem kraju, spowodowały, że trend odwracania się Stanów Zjednoczonych od Europy został gwaltownie zastopowany. Imperialna polityka Władimira Putina wobec Ukrainy uzmysłowiła administracji Obamy, podobnie zresztą jak wielu politykom europejskim, że stabilność w Europie nie jest stanem danym naszemu kontynentowi raz na zawsze. Że poczucie bezpieczeństwa Europy może być złudne i ulotne, a Rosja znowu staje się zagrożeniem dla ustalonego na kontynencie porządku.

Grozę sytuacji potęgował fakt, że nie było wiadomo, jak daleko sięgają aspiracje rosyjskiego przywódcy. Czy stosując taktykę „,miękkiej destabilizacji”, czyli wojny psychologicznej i działań propagandowych, nie chce on objąć swoimi imperialnymi ambicjami innych, byłych republik radzieckich: Litwy, Łotwy i Estonii? Przecież także wobec tych państw można było zastosować swego rodzaju doktrynę Putina, zakładającą ochronę w sąsiednich krajach interesów etnicznych Rosjan z użyciem wojska, jeśli tylko Rosja uznałaby, że te interesy są albo mogą być zagrożone (Menkiszak, 2014). Poczucie bezpieczeństwa uległo zachwianiu także w innych państwach dawnego bloku sowieckiego, choćby w Polsce, gdzie wprawdzie nie było mniejszości rosyjskiej, ale samo położenie $w$ bezpośrednim sąsiedztwie ogarniętego wojną regionu oraz przykre doświadczenia $\mathrm{z}$ historii potęgowały atmosferę zagrożenia.

Niewątpliwie, konflikt na Ukrainie stał się wielkim wyzwaniem dla układu transatlantyckiego. Skala tego wyzwania kazała wierzyć, że nie będzie to reakcja podobna do tej z sierpnia 2008 r., gdy to społeczność międzynarodowa, w tym Stany Zjednoczone i Europa, raczej z tolerancją odniosły się do agresywnych działań Rosji w Gruzji. Wprawdzie udało się wówczas - dzięki zaangażowaniu prezydenta Nicolasa Sarkozy’ego, 
występującego w imieniu Unii Europejskiej (sic!) - powstrzymać ofensywę rosyjską i tak naprawdę ocalić Gruzję, to jednak zabrakło wobec Rosji czegoś na kształt sankcji karzących. Teraz zresztą - w nawiązaniu do sytuacji sprzed sześciu laty - pojawily się komentarze, że właśnie ówczesna stosunkowo słaba reakcja Unii Europejskiej i Stanów Zjednoczonych, w tym wyjątkowa bierność prezydenta Busha, stanowily rodzaj impulsu dla obecnych agresywnych poczynań Putina. Mógł on bowiem zakładać, że podobnie jak było w przypadku Gruzji, także tym razem świat zachodni nie będzie skory do gwaltownych i nieprzyjemnych dla Rosji akcji. Że nie będzie w stanie odbudować jedności działania wobec Moskwy.

Jednak waga Ukrainy w układzie europejskim zdawała się być czymś znacznie większym niż Gruzji, niewielkiego kraju, pozostającego trochę na peryferiach Europy. Zresztą inaczej niż w przypadku wojny rosyjsko-gruzińskiej, gdzie jakoś można było dochodzić też racji Rosji, to aneksja Krymu i inspirowane przez Moskwę zbrojne działania rebeliantów we wschodniej Ukrainie były aktami agresji na suwerenne państwo, sprzecznymi z międzynarodowymi standardami. Należało zatem sądzić, że tym razem społeczność międzynarodowa zareaguje zdecydowanie i ostro. Instynktownie też czuło się, że w momencie tak kluczowym i dramatycznym, jak wydarzenia na Ukrainie, grożące eskalacją zagrożenia i podważające bezpieczeństwo europejskie, jedynym skutecznym przeciwdziałaniem będzie solidarna postawa Ameryki i Europy wobec Moskwy. Tak więc kryzys ukraiński miał być ważnym testem dla układu transatlantyckiego. Ale w pierwszym rzędzie testem dla amerykańskiego przywództwa we wspólnocie transatlantyckiej.

Jeśli wykluczyć ewentualną wojskową pomoc amerykańską dla Ukrainy, która na początku - biorąc pod uwage generalną niechęć administracji Obamy do udzielania wsparcia militarnego, nawet $\mathrm{w}$ formie dostaw sprzętu wojskowego, oraz postawe społeczeństwa amerykańskiego ${ }^{5}$ - wydawała się mało realna, to nie ma wątpliwości, że w rozgrywającym się dramacie ukraińskim, Stany Zjednoczone dysponowały stosunkowo słabymi kartami, a przynajmniej słabe były te, które Waszyngton mógł i chciałby wykorzystać. Biorąc pod uwagę fakt, że powiązania gospodarcze między Stanami Zjednoczonymi a Rosją nie miały strategicznego dla Moskwy znaczenia, to na przykład zastosowanie sankcji ekonomicznych i handlowych nie musiało być dostateczną formą presji, zmuszającą Kreml do odejścia od awanturniczej, imperialnej polityki. Ale zrobić coś należało.

Trzeba też przyznać, że riposta Stanów Zjednoczonych na działania Moskwy była stosunkowo ostra. Najpierw w słowach. Prezydent Obama, w pierwszej reakcji na zbrojną operację krymską, zapowiadał, że Rosja „zapłaci cenę za agresję przeciwko Ukrainie”, zaś sekretarz stanu John Kerry słał komunikat, że „Rosja dokonuje aktu agresji i łamie prawo międzynarodowe”, a potem groził, że „będziemy ją izolować politycznie i ekonomicznie, jeśli nie zaprzestanie inwazji na Ukrainę". Jeszcze mocniej brzmiały słowa wypowiadane przez polityków z opozycyjnej Partii Republikańskiej. John Boehner, przewodniczący Izby Reprezentantów, nazywał Putina „bandziorem”,

5 Tylko 18 proc. Amerykanów uważalo, że USA powinny bronić Ukrainy przed Rosją, 46 proc. -że nie powinny, a 36 proc. nie miało zdania - takie byly wyniki sondażu przeprowadzonego 2 marca 2014 r. na zlecenie portalu (Huffington Post, 2014). 
a inni republikańscy przedstawiciele $\mathrm{w}$ Kongresie zarzucali gospodarzowi Białego Domu zbyt łagodne dotąd traktowanie rosyjskiego przywódcy. Miał też niewątpliwie wiele racji republikański senator Lindsay Graham, gdy konstatował: „Putin uważa Obamę za człowieka o słabym charakterze". Sugerował skierowanie do Rosji następującego komunikatu: „To, co robicie, jest nielegalne i Ameryka podejmie zdecydowane działania, jeśli natychmiast nie wycofacie wojsk z Krymu" (USA Today, 2014).

Za słowami poszły działania. Odpowiadając na aneksję Krymu, administracja Obamy niemal natychmiast, bo już na początku marca 2014 r., wprowadziła pierwsze sankcje - restrykcjami objęto m.in. kilka finansowych instytucji w Rosji, a zakazem wjazdu do Stanów Zjednoczonych - niektóre osobistości z otoczenia prezydenta Putina. Nie były to restrykcje o znaczeniu egzystencjalnym dla Rosji, jednak miały swój ciężar polityczny. Prestiżowe zaś znaczenie miała niewątpliwie decyzja o zawieszeniu przez Stany Zjednoczone przygotowań do planowanego na czerwiec 2014 r. w Soczi szczytu państw najbardziej rozwiniętych gospodarczo - G-8. A następnie - po podobnych decyzjach innych krajów członkowskich tego gremium - przeniesienie spotkania do Brukseli, wreszcie wręcz wykluczenie Rosji z grona państw G-8, które tym samym powróciło do pierwotnej formuły G-7. Zresztą przynależność Federacji Rosyjskiej do tego elitarnego klubu była - biorąc pod uwagę jej potencjał i porównując go z rangą gospodarczą pozostałych państw Grupy, czyli Stanów Zjednoczonych, Niemiec, Wielkiej Brytanii, Francji, Włoch, Kanady i Japonii - swego rodzaju oksymoronem, zresztą mocno Rosję dowartościowującym.

Ta dość zdecydowana reakcja Waszyngtonu jawiła nam się jeszcze wyraźniej na tle pierwszych działań, a bardziej braku konkretnych kroków po stronie sojuszników europejskich. Unia Europejska bowiem - chociaż zaprezentowała pewną stanowczość, a nawet zdobyła się na bardzo krytyczne słowa skierowane pod adresem Rosji, daleko bardziej wykraczające poza tradycyjną dla niej inercję i wstrzemięźliwość - to jednak nadal miała kłopoty z wypracowaniem jednoznacznego, ostrego stanowiska. Tymczasem było bardzo ważne, aby tym razem Ameryka i Europa zaprezentowały solidarną wobec wydarzeń na Ukrainie postawę.

Nie chodziło tylko o to, że wspólne działania restrykcyjne wobec Rosji zwiększały ich skuteczność. Należało wziąć pod uwagę także kwestię odbudowy czegoś, co Lee Feinstein, dyplomata i analityk amerykański, nazwał „niezłomnością transatlantyckiej wspólnoty" (Feinstein, 2014). Byłaby to też adekwatna odpowiedź na oczekiwania administracji Obamy, że jego europejscy sojusznicy okażą się ważnymi graczami na arenie międzynarodowej. Tym bardziej że kryzys toczył się przecież niemalże u ich granic i de facto zagrażał bezpieczeństwu w Europie. Gdyby Stanom Zjednoczonym udało się zbudować silną i zdeterminowaną koalicję Zachodu w obronie integralności terytorialnej Ukrainy, zdecydowaną zastosować ostre restrykcje wobec Rosji i tym samym powstrzymać Putina, wzmocniłyby swoją pozycję nie tylko w ramach układu transatlantyckiego, ale i w skali globalnej. Stawka była więc wysoka.

W tej rozgrywce z Moskwą to właśnie państwa europejskie dysponowały silnymi kartami. Przede wszystkim dlatego, że wiele z nich było ważnymi partnerami handlowymi Rosji, nabywając jej surowce energetyczne, stanowiące podstawowy towar eksportowy, bez którego Rosja straciłaby około 90 proc. swoich dochodów dewizowych. Wyjątkowe atuty w tej rozgrywce posiadała na przykład Wielka Brytania, która była 
swego rodzaju przystanią dla rosyjskich oligarchów i mogła te finansowe depozyty bogatych Rosjan wykorzystać jako szczególną siłę nacisku. Trudną do przecenienia wartością dla Rosji była też zachodnia technologia i zachodni kapitał, bez których gospodarka rosyjska miałaby duże kłopoty.

Ale to, co było atutem strony europejskiej, rodziło też obawy o konsekwencje dla gospodarki poszczególnych państw Unii Europejskiej, gdyby nałożono na Rosję sankcje handlowe lub ekonomiczne. Bo przecież miliardowe kontrakty Europy na dostawy rosyjskiej ropy naftowej i gazu ziemnego - Rosja sprzedała do Europy w 2012 r. surowce i towary nieprzetworzone o wartości aż $175 \mathrm{mld}$ euro - oznaczały uzależnienie większości państw wspólnoty europejskiej od rosyjskich surowców energetycznych. To kraje europejskie, zwłaszcza z Europy Środkowo-Wschodniej, były zainteresowane rosyjskim rynkiem, na który wysyłały swoje towary o wartości ponad 120 mld euro. W porównaniu z tym eksport rosyjski do Stanów Zjednoczonych wyniósł w 2013 r. jedynie 27 mld dol., a import - 11,2 mld dol. Biorąc te elementy pod uwagę, to wprowadzenie sankcji gospodarczych przez Unię Europejską groziło rewanżem Moskwy - zastosowaniem własnych restrykcji handlowych, znacznie bardziej dotkliwych dla państw europejskich niż dla gospodarki amerykańskiej.

Jednak wspólne działanie Stanów Zjednoczonych i Unii Europejskiej miało znaczenie fundamentalne - tylko takie w odniesieniu do Rosji mogło być skuteczne. Dlatego prezydent Obama nie ustawał w wysiłkach, aby nakłonić Unię Europejską do transatlantyckiej solidarności w kwestii ukraińskiej - zdecydowanego i wzajemnie się uzupełniającego działania wobec Rosji. To był dominujący temat rozmów Obamy podczas jego pierwszej (sic!) w prezydenckiej karierze wizyty w instytucjach unijnych w Brukseli. Uczestnicząc pod koniec marca 2014 r. w szczycie UE-USA, prezydent Obama próbował nakłonić partnerów europejskich, aby nie zważając choćby na wyjątkowo silne uzależnienie od dostaw rosyjskich surowców energetycznych, przeciwstawili się polityce Rosji, nakładając na nią sankcje gospodarcze. Wprawdzie Unia Europejska - odpowiadając na aneksję Krymu - przygotowała listę Rosjan, którym zamrożono aktywa oraz zakazano wjazdu na terytorium państw UE (lista ta była sukcesywnie rozszerzana), a także zapowiedziano możliwość wprowadzenia sankcji gospodarczych wobec Rosji w sytuacji, gdyby Moskwa dalej działała destabilizująco na Ukrainie, to jednak było to znacznie mniej ambitne od tego, czego oczekiwały Stany Zjednoczone.

Prezydent Obama apelował do Europy o wspólne z Ameryką działania wobec Rosji, ale tej solidarności nie było lub było jej niewiele choćby dlatego, że brakowało jej w samej Unii Europejskiej. Powodem było zróżnicowane podejście poszczególnych państw członkowskich UE do Rosji, wynikające głównie ze skali ich gospodarczych powiązań z Moskwą, ale też swoistego stosunku do Rosji - w końcu rozległego, bliskiego geograficznie mocarstwa eurazjatyckiego. Wyrażało się to choćby w nieustających od wielu lat próbach włączenia Federacji Rosyjskiej do europejskiej gry sił, ale też utrzymywaniu ,specjalnych" stosunków niektórych stolic europejskich z Moskwą. Działania te były w jakiś sposób uzasadnione - budowa trwałego układu bezpieczeństwa w Europie, a także podołanie różnym wyzwaniom globalnym bez współpracy z Rosja, jeśli nie było niemożliwe, to przynajmniej znacznie trudniejsze.

W niektórych wypadkach zaś decydowały różnej natury sentymenty - historyczne, gospodarcze i polityczne. W efekcie wypowiedzi i zachowania Viktora Orbána na 
Wegrzech, Roberta Ficy na Słowacji czy Wasyla Sztonowa, ministra gospodarki Bułgarii, wyrażające sprzeciw wobec sankcji, ilustrowały trudności, jakie napotykała Unia Europejska w praktyce politycznej - w wypracowaniu wspólnego wobec Rosji działania. Tym samym podważano to, co było niekwestionowanym atutem i główną siłą Unii Europejskiej - instytucji opartej na wspólnocie interesów i wartości, a solidarność stanowiła jedną z owych podstawowych wartości UE.

Zresztą Waszyngton, i to nie tylko czasu Obamy, kalkulował w podobny sposób - dobre relacje z Rosją mają znaczenie nie tylko przy rozwiązywaniu doraźnych problemów, ale także wpływają na proces budowy ładu międzynarodowego. Stąd słynne „resetowanie” stosunków z Rosją, które administracja Obamy realizowała przez całą swą pierwszą kadencję. I trzeba uczciwie przyznać, odniosła na tym polu sukcesy, choćby podpisanie nowego traktatu START, poważnie ograniczającego liczbę amerykańskich i rosyjskich głowic nuklearnych, czy możliwość wykorzystania poradzieckiej przestrzeni dla amerykańskich transportów kierowanych do Afganistanu. Także pośrednie przyzwolenie Rosji na zbrojną interwencję sił NATO w Libii podczas ,,arabskiej wiosny" w 2011 r. - Rosja, podobnie jak Chiny nie zastosowała weta w Radzie Bezpieczeństwa - zdawało się sugerować, że reset się opłaca.

Jednak ceną tego było pogorszenie relacji Stanów Zjednoczonych z niektórymi krajami Europy Środkowo-Wschodniej, przegrywającymi w Waszyngtonie swoje interesy w zestawieniu $z$ atutami Rosji. Tak bowiem odebrano fakt rezygnacji przez administrację Obamy z projektu systemu obrony antyrakietowej, którego elementy miały być instalowane w Polsce i Czechach, a czemu zdecydowanie sprzeciwiała się Moskwa. Gdy więc w myśleniu ekipy Obamy to Rosja stała się państwem o szczególnym znaczeniu, zdecydowano się na odstąpienie od ustalonej już z Warszawą i Pragą koncepcji „, tarczy antyrakietowej", starając się w ten sposób zadośćuczynić oczekiwaniom Moskwy (Kiwerska, 2013c, s. 63-66).

Teraz jednak Biały Dom zdawał się prezentować inny punkt widzenia - na obecnym etapie $\mathrm{w}$ relacjach z Rosją właśnie czynnik ukraiński powinien być traktowany jako wyznacznik strategiczny, przesądzający o zdecydowanej reakcji na działania Kremla. W Waszyngtonie uznano, że Ukraina ma kluczowe znaczenie dla bezpieczeństwa Europy, a zwłaszcza jej wschodniej części. Przyzwolenie na realizację ekspansywnych ambicji Putina wobec tego państwa może doprowadzić do dalszych groźnych dla porządku europejskiego konsekwencji. Nie można wykluczyć, że przy okazji chodziło o odzyskanie przez administrację Obamy niekwestionowanej inicjatywy na arenie międzynarodowej i zamanifestowanie swej skuteczności w politycznym starciu z Putinem.

Tymczasem czynnik ukraiński takiego wpływu na zachowania państw Unii Europejskiej nie miał lub oddziaływanie to było silnie uzależnione od interesów poszczególnych państw i skali ich powiązań z Rosją. Trudno o bardziej dosadne opisanie istoty postawy krajów unijnych, niż to zaprezentowane przez brytyjskiego publicystę Edwarda Lucasa podczas jego wystapienia w lipcu 2014 r. przed komisją spraw zagranicznych Senatu USA. Lucas mówił: „W Brukseli, Londynie i Berlinie wielu wierzy, że Rosję Putina da się oswoić poprzez dyplomację. Że pieniądze nie śmierdzą. Że energia to tylko biznes. Że nie trzeba podejmować radykalnych kroków w odpowiedzi na ukraiński kryzys. Że niebezpieczna jest polityka nie łagodzenia, tylko zbyt ostra reakcja" (Testimony, 2014). 
I chociaż można uznać argumenty wielu państw wspólnoty europejskiej, zwłaszcza odnoszące się do wagi gospodarczych powiązań z Rosja, ich uzależnienia od dostaw rosyjskich surowców energetycznych. Można też zgodzić się z opinią, że wypracowanie konsensu przez 28 państw nie było sprawą prostą, a na pewno było procesem trudniejszym niż ten, z którym miał do czynienia amerykański prezydent, podejmujący najczęściej decyzje samodzielnie. Wszak prezydent Obama nie musiał ustalać swego stanowiska w żmudnych i gorących dyskusjach, co charakteryzowało gremia unijne, nie musiał też - inaczej niż przywódcy wielu krajów europejskich - obawiać się wysokich kosztów wprowadzanych sankcji.

Te zaś powodowały, że na przykład w Niemczech przeciwko sankcjom były kręgi biznesu, którego przedstawiciele zainwestowali w Rosji miliardy euro. Sytuację kanclerz Merkel, forsującej ostre stanowisko wobec Kremla, komplikował fakt, że jej koalicjant rządowy - SPD, od lat opowiadający się za bliską współpracą z Moskwa, także i teraz nie chciał twardego traktowania Rosji. Argumentem była również tradycyjna skłonność większości państw członkowskich Unii Europejskiej do preferowania rozwiązań łagodnych, dyplomatycznych, a nie forsowania - tak jak zwykli to czynić Amerykanie - działań silnie restrykcyjnych, jakby w nawiązaniu do słynnego stwierdzenia Roberta Kagana - „Amerykanie z Marsa, Europejczycy z Wenus” (Kagan, 2003).

To wszystko jednak wyglądało zupełnie inaczej z perspektywy amerykańskiej. Administracja Obamy miała prawo sądzić, że w obliczu kryzysu na Ukrainie, wywołanego groźną - szczególnie dla Europy - polityką Putina, sojusznicy europejscy zachowają się z większą determinacją i będą bardziej skuteczni. Zastosują stanowcze sankcje wobec Moskwy, a nie ograniczą się tylko do ostrej retoryki i zapowiadanego planu wprowadzania restrykcji. Tak się nie działo. Oceny tej nie zmieniło zasadniczo podpisanie przez Unię Europejską z Ukrainą w czerwcu 2014 r. specjalnej umowy stowarzyszeniowej, najpierw jej czę́ci politycznej, a następnie handlowej (Pifer, 2014). W ocenie amerykańskiej konflikt na Ukrainie obnażył słabość Unii Europejskiej zarówno w działaniach ekonomicznych, jak i politycznych. Ujawnił podziały we wspólnocie europejskiej, uniemożliwiające szybkie podjęcie decyzji. Unia Europejska okazała się strukturą mało koherentną i niezdecydowaną.

Nie będzie więc przesady w stwierdzeniu, że Unia Europejska na początku jakby oddała Ameryce przywództwo w sprawie Ukrainy i konfliktu z Moskwą. Można nawet zaryzykować opinię, że była z tego dość zadowolona. A przecież to nie Stany Zjednoczone w pierwszym rzędzie powinny zabiegać o utrzymanie pokoju i stabilizacji w Europie. Posiadając tak znaczącą strukturę jak Unia Europejska, wyposażoną w odpowiednie narzędzia, to państwa europejskie winny ostro zareagować na działania Moskwy, zagrażające nie tylko suwerenności Ukrainy, ale także porządkowi na ich kontynencie. Tak się nie działo i to właśnie Stany Zjednoczone jako pierwsze i przez pewien czas jedyne zmierzyły się naprawdę z ambicjami Rosji. Próbując je powstrzymać, wprowadzały sukcesywnie i zdecydowanie kolejne sankcje wobec Moskwy (jeszcze przed tragedią malezyjskiego boeinga Waszyngton zastopował długoterminowe kredyty dla niektórych rosyjskich koncernów i banków).

Nie będzie też ryzykowną teza, że dopiero tak dramatyczne wydarzenie, jak zestrzelenie 17 lipca 2014 r. pasażerskiego samolotu - najprawdopodobniej przez rosyjskich separatystów - spowodowało zmianę zachowania państw członkowskich UE i ich 
większą determinację w działaniach wobec Moskwy. Tragiczna śmierć 298 pasażerów malezyjskiego samolotu, w tym obywateli wielu państw europejskich (wśród ofiar było aż 173 Holendrów), bezpośrednio obciążała prezydenta Putina. To Rosja zbroiła i wyposażała rebeliantów oraz wysyłała na wschodnią Ukrainę rosyjskich żołnierzy. Trzeba było zatem tak wielkiej zbrodni, aby Unia Europejska zdecydowała się na zastosowanie wobec Rosji sankcji gospodarczych. Co ważne, skala i charakter tych restrykcji zaskoczyły nawet największych sceptyków, wątpiących w możliwość tak silnego uderzenia Unii Europejskiej. Wprowadzone pod koniec lipca 2014 r. sankcje sektorowe, wymierzone w kluczowe działy gospodarki Rosji, obejmowały m.in. rosyjskie banki i przedsiębiorstwa, które odcięto w dużym stopniu od międzynarodowych rynków kapitałowych. Bolesne były też restrykcje związane z sektorem energetycznym - zakazano eksportu technologii. Ponadto zablokowano niektóre transakcje na sprzęt zbrojeniowy, a także rozszerzono sankcje personalne.

Trudno przesądzić o skuteczności podjętych wobec Moskwy restrykcji, podobnie jak nie można było precyzyjnie ocenić kosztów wprowadzonych sankcji dla państw europejskich - wszak tego typu ograniczenia są bronią obosieczną. Tym bardziej że Rosja niemal natychmiast ogłosiła własne restrykcje ekonomiczne, sprowadzające się najczęściej do zablokowania importu towarów rolnych z państw, które zastosowały wobec niej sankcje. W każdym razie po roku obowiązywania sankcji można było powiedzieć, że rosyjska gospodarka coraz silniej odczuwała ich skutki, na pewno były one bardziej dotkliwe dla Rosji niż rosyjskie retorsje dla sytuacji gospodarczej państw członkowskich Unii Europejskiej i Stanów Zjednoczonych.

Najważniejszym jednak aspektem całej sytuacji było to, aby Unia Europejska, która niewątpliwie w swej polityce wobec Rosji „przekroczyła Rubikon”, pozostała konsekwentna - wytrwała w tej solidarnej i zdeterminowanej postawie, realizując dalej politykę sankcji i ograniczeń w zależności od działań Moskwy. Chodziło - rzecz jasna - o możliwość osiagnięcia celu - zmuszenie prezydenta Putina do rewizji polityki i odstąpienia od agresywnych działań wobec Ukrainy. Czy to się uda, można nadal mieć wiele wątpliwości (Gaddy, Ickes, 2014). Nie mniej jednak potwierdzeniem konsekwencji prowadzonej przez Unię Europejską polityki sankcji wobec Rosji było ich zaostrzenie we wrześniu 2014 r. (pod wpływem eskalacji rosyjskich działań na wschodzie Ukrainy), a następnie przedłużanie na kolejne miesiące: najpierw w marcu 2015 r., a potem w czerwcu 2015 r. (na mocy tej ostatniej decyzji będą one obowiązywać co najmniej do końca stycznia 2016 r.).

A zatem zachowanie unijnej solidarności stało się na tym etapie konfliktu ukraińskiego niewątpliwie faktem, co mogło tylko cieszyć amerykańskiego partnera. Stosunkowo ostry kurs polityki Unii Europejskiej wobec Rosji świadczył o tym, że ta wspólnota - słusznie krytykowana za brak determinacji i pewną inercję - potrafiła się jednak zmobilizować. Unia Europejska pokazała, że jest zdolna - choć niespiesznie i z oporami - podjać decyzje potwierdzające jej potencjał. Zademonstrowała swe możliwości odgrywania aktywnej roli na arenie międzynarodowej. Co więcej, Unia Europejska zadziała w sposób, jaki oczekiwał od niej Waszyngton. W odniesieniu do przypadku Rosji politycy po obu stronach Atlantyku, w efekcie utrzymującego się zaangażowania militarnego Rosji we wschodniej Ukrainie, zdawali się podobnie myśleć o euroazjatyckim mocarstwie - jako o państwie, które nie jest siłą racjonalną i kon- 
struktywną, wręcz przeciwnie - stanowi zagrożenie i wyzwanie, które należy wspólnie przezwyciężyć. Nie ma wattpliwości, że koordynacja i jedność w działaniu Ameryki i Europy stanowiły najbardziej skuteczny sposób oddziaływania na Moskwę, a tym samym pożądany czynnik kształtowania sytuacji międzynarodowej.

Był jeszcze jeden aspekt konfliktu na Ukrainie. Zagrożenie wywołane ekspansywną polityką Rosji stało się czynnikiem umocnienia związków militarnych i politycznych między Stanami Zjednoczonymi a ich europejskimi sojusznikami, ostatnio dość nadwyrężonych. Należy podkreślić, że także wskutek działań administracji Obamy, ograniczającej swe zainteresowanie bezpieczeństwem Europy. Wszak Stary Świat wydawał się Amerykanom stabilny i pozbawiony wrogów, zagrażających jego ładowi. Prezydent Putin swoimi działaniami wobec Ukrainy to złudzenie zburzył, szczególnie w odniesieniu do Europy Srodkowej i Wschodniej.

Deklaracje administracji Obamy o rozszerzeniu i wzmocnieniu amerykańskiej obecności wojskowej w Europie pojawiły się niemal u początku konfliktu ukraińskiego, gdy tylko się ujawniły rosyjskie aspiracje imperialne wobec Krymu. Wyrażone zostały zaś najsilniej podczas wizyty prezydenta Obamy w Polsce, na uroczystościach 25-lecia Wolności, w czerwcu 2014 r. To wówczas padty słowa o wzmocnieniu wschodniej flanki NATO sumą $1 \mathrm{mld}$ dol. oraz deklaracja o zwiększeniu liczby żołnierzy i sprzętu amerykańskiego w naszej części kontynentu. Zapowiedzi te prezydent Obama powtórzył trzy miesiące później, podczas pobytu w Tallinie. Jednodniowa wizyta w stolicy Estonii była demonstracją poparcia Ameryki dla krajów bałtyckich, traktowanych przez Rosję jako „,bliska zagranica”. Amerykański prezydent mówił: „Będziemy bronić naszych sojuszników w NATO, wszystkich sojuszników. [...] Bezpieczeństwo Tallina, Rygi i Wilna jest tak samo ważne jak bezpieczeństwo Berlina, $\mathrm{Pa}$ ryża i Londynu" (Remarks, 2014).

Wcześniej takie deklaracje o odpowiedzialności Ameryki za bezpieczeństwo Europy Środkowej i Wschodniej z ust prezydenta Obamy nie padły. Raczej można było mieć wątpliwości czy wobec nacisku na ,resetowanie” stosunków z Rosją interesy naszej części kontynentu są realnie brane w Waszyngtonie pod uwagę. Wystarczy przypomnieć kunktatorską taktykę administracji Obamy w kwestii instalowania w Polsce i Czechach elementów „tarczy antyrakietowej”, czy ujawnioną przez media poufną rozmowę Obamy z prezydentem Dmitrijem Miedwiediewem, w marcu 2012 r., dowodzącą braku lojalności prezydenta USA wobec swych sojuszników z Europy Środkowo-Wschodniej. Teraz wrażenie było zupełnie inne - nastapiło przewartościowanie amerykańskich priorytetów w zakresie bezpieczeństwa. Z korzyścią dla całego układu transatlantyckiego.

Chociaż zapowiedzi odnoszące się do wschodniej części kontynentu wzmacniały poczucie bezpieczeństwa jej mieszkańców, to jednak znacznie większy wymiar miały konkretne działania podejmowane w ramach NATO. Nie tylko utwierdzały one range i znaczenie tego bezprecedensowego sojuszu militarno-politycznego, ale też przywracały mu sens istnienia. Zwłaszcza, gdy atuty te wyraźnie nadszarpnęła wątpliwa skutecznie i niechętnie realizowania przez europejskich sojuszników misja NATO w Afganistanie. Tymczasem agresywna polityka Putina spowodowała, że państwa członkowskie Sojuszu, dostrzegając na horyzoncie realne zagrożenie, zaczęy „,zwierać szeregi" i umacniać swoje zdolności militarne. 
Podczas szczytu NATO w Newport, na początku września 2014 r., przywódcy państw członkowskich podjęli decyzję o utworzeniu tzw. szpicy NATO, czyli nowych sił szybkiego reagowania liczących - jak zakładano - 4 tys. żołnierzy. Przesądzili także konieczność wzmocnienia zdolności obronnych wschodniej flanki Paktu, nawet w formie lokalizacji tam baz wojskowych i struktur dowodzenia, a także - choćby rotacyjnej - obecności amerykańskich żołnierzy, wreszcie zapowiedzieli intensyfikację manewrów wojskowych w państwach wschodniej części Sojuszu. Te fundamentalne decyzje nie tylko określały strategię Sojuszu na nową zimną wojnę - jak już zaczęto określać czas wyznaczony rosyjską agresją na Ukrainę, ale przede wszystkim na powrót czyniły z NATO skuteczny i najważniejszy filar współpracy transatlantyckiej, odstraszający potencjalnych wrogów. W Newport bowiem zamanifestowano, że głównym zadaniem Sojuszu pozostaje - jak stwierdził Jens Stoltenberg, sekretarz generalny NATO - ,wspólna odpowiedzialność za bezpieczeństwo wszystkich sojuszników" i co do tego nikt już nie powinien mieć wątpliwości (Stoltenberg, 2014). Oznaczało to, że ewentualna eskalacja imperialnych ambicji Putina na któreś z państw członkowskich NATO spotka się $\mathrm{z}$ adekwatną reakcją Sojuszu, zgodnie z art. 5 traktatu waszyngtońskiego.

To, co mogło zaskakiwać, obserwując przebieg szczytu w Newport, to niezwykła zgodność postaw i opinii wyrażanych przez państwa członkowskie Sojuszu. Już dawno nie było takiej manifestacji wspólnoty przy natowskim stole obrad. I choć zamierzenia NATO oznaczały większy wysiłek finansowy poszczególnych państw członkowskich, które przecież tradycyjnie opierały się wzrostowi nakładów budżetowych na obronę do wymaganych 2 proc., to jednak sprzeciwu nie było. Poczucie zagrożenia ze strony Rosji miało decydujący wpływ na postawę większości państw członkowskich. Zmuszało też do zachowania pełnej solidarności, jakkolwiek mogło to wymagać pewnych ofiar. Tak należy ocenić fakt, że Francja podjęła decyzję wstrzymującą przekazanie Rosji desantowca typu Mistral, ryzykując tym samym miliardową karę i utratę miejsc pracy w stoczniach (ostatecznie jednostka nie została do Rosji wysłana).

Nasuwa się zatem konstatacja. Chociaż brzmi ona nieprzyzwoicie, biorąc pod uwagę skalę i konsekwencje konfliktu rozgrywającego się za naszą wschodnią granica, to jednak w dramacie Ukrainy można było dostrzec coś pozytywnego. Po pierwsze, agresywna polityka prezydenta Putina spowodowała stosunkowo silne „,wzmożenie” polityczne Unii Europejskiej. Nałożenie unijnych sankcji na Rosję oraz konsekwentne utrzymywanie tej restrykcyjnej polityki - mimo że uderzała ona w interesy niektórych państw członkowskich i była negowana przez różne kręgi biznesu i polityki w Europie - oznaczało, że solidarność pozostaje nadrzędną wartością Unii Europejskiej. I to już samo w sobie było pozytywnym aspektem sprawy.

Po drugie, Unia Europejska - przynajmniej w pewnym stopniu - spełniła oczekiwania Stanów Zjednoczonych, że stanie się skutecznym graczem na arenie międzynarodowej. Skala zastosowanych przez Europę sankcji była dość duża i już to dawało większe gwarancje ich skuteczności. Sam fakt, że restrykcje Unii Europejskiej wprowadzano w koordynacji ze Stanami Zjednoczonymi (choć lepiej byłoby powiedzieć, że pod ich naciskiem), potwierdzał istnienie „niezłomności transatlantyckiej wspólnoty”.

Po trzecie, umocnieniu tej wspólnoty służyły jednak przede wszystkim działania w ramach NATO. Konsekwencją decyzji wszystkich państw członkowskich stało się zwiększenie zdolności obronnych Sojuszu poprzez utworzenie „szpicy”, zdolnej do 
walki w ciągu 48 godzin, przerzucenie do Europy dodatkowo amerykańskiego ciężkiego uzbrojenia, wreszcie następowało militarne wzmocnienia wschodniej flanki NATO. Mogło to oznaczać, że takimi posunięciami Sojusz podsyca wojenną atmosferę w Europie. Jednak ważniejsze od tego zarzutu są inne efekty podejmowanych działań - obok czytelnego sygnału dla Kremla, że NATO jest gotowe do przeciwstawienia się rosyjskiemu wyzwaniu, to nastąpiły konsolidacja i umocnienie układu transatlantyckiego na skalę od dawna nieobserwowaną. Agresywna polityka Putina sprawiła, że wspólnota transatlantycka - jako jedyna siła zdolna przeciwstawić się Rosji - odzyskała sens istnienia. Trudno znaczenie tego faktu przecenić.

\section{Bibliografia}

Applebaum A. (2008), Wybita godzina Europy, „Gazeta Wyborcza”, 31.07.

Brzeziński Z. (2008), Bez przesady z symbolami, ,Rzeczpospolita”, 24-26.12.

Brzeziński Z. (2010), From Hope to Audacity. Appraising Obama’s Foreign Policy, „Foreign Affairs", January/February, nr 1.

Cantalapiedra D. G. (2009), Perceptions on US Policy, Transatlantic Relations, and the Alliance Security Dilemma, w: Perceptions and Policy in Transatlantic Relations. Prospective visions from the US and Europe, red. N. F. Sola, M. Smith, London-New York.

EU-US summits to take place 'only when necessary', 27.03.2010, www.euobserver.com/ 9/29782?print $=1$.

Feinstein L. (2014), Przysylajac samoloty, demonstrujemy stanowczość, „Gazeta Wyborcza”, 17.03.

Gaddy C. G., Ickes B. W. (2014), Can Sanctions Stop Putin?, June 3, 2014, www.brookings.edu/research/articles/2014/06/03-can-sanctions-stop-putin-gad.

Götz M. (2013), Gospodarcze aspekty stosunków transatlantyckich, „Przegląd Zachodni”, nr 1.

Haass R. N. (2011), Why Europe no longer matters, 15.06.2011, www.washingtonpost.com/opinions/why-europe-no-longer-matters/2011/06/15/AG7eCCZH_story_1.html.

Hasselbach Ch. (2009), Opinion: Clinton's European Visit Marks a New Beginning, 7.03.2009, www.dw-world.com/popups/popup/_printcontent/"4079093,00.html.

Huffington Post (2014), www.huffingtonpost.com/2014/03/03/ukraine-poll_n_4891224.html.

Indyk M. S., Lieberthal K., O'Hanlon M. E. (2012), Bending History. Barack Obama's Foreign Policy, Washington D.C.

Kagan R. (2010), Obama - cudu nie byto, „Gazeta Wyborcza”, 16-17.01.2010.

Kagan R. (2003), Of Paradise and Power: America and Europe in the World Order; New York (wyd. polskie: Potegga i raj. Ameryka i Europa w nowym porzadku świata, Warszawa 2003).

Kagan R. (2012), Why the World Needs America, February 11, 2012, www.brookings.edu/articles/2012/0211_us_power_kagan.aspx?p=1.

Khanna P. (2009), Pożegnanie z hegemonia, „Europa”. Dodatek do „Dziennika”, 7-8.03.2009.

Kirchner E., Sperling J. (2007), EU Security Governance, Manchester-New York.

Kiwerska J. (2011), Niemcy we wspólnocie transatlantyckiej, w: J. Kiwerska, B. Koszel. M. Tomczak, S. Żerko, Polityka zagraniczna zjednoczonych Niemiec, Poznań.

Kiwerska J. (2013c), Europa w strategii Baracka Obamy (2009-2012), IZ Policy Papers, nr 10, Poznań. 
Kiwerska J. (2013b), Rozchodzenie się dwóch światów? Stany Zjednoczone i relacje transatlantyckie 1989-2012, Poznań.

Kiwerska J. (2013a), Stany Zjednoczone wobec kryzysów regionalnych - aspekt transatlantycki, IZ Policy Papers, Poznań.

Kupchan Ch. A. (2009), NATO's Hard Choices, „The New York Times”, 31.03.2009.

Menkiszak M. (2014), Doktryna Putina: tworzenie koncepcyjnych podstaw rosyjskiej dominacji na obszarze postradzieckim, Komentarze OSW, nr 131/28.03.2014, http://www.osw.waw.pl/ sites/default/files/komentarze_131.pdf.

Michta A. A. (2011), Ameryka czeka na Europe, „Gazeta Wyborcza”, 28.03.

National Security Strategy, May 2010, www.whitehouse.gov/sites/default/files/rss_viewer/national_security_strategy.pdf.

Obama B. (2011), Potrzebujemy siebie nawzajem, „Polityka”, 8-14.06.

Pifer S. (2014), Poroshenko Signs EU-Ukraine Association Agreement, June 27, 2014, www.brookings.edu/blogs/up-front/posts/2014/06/27-poroshenko-signs-eu-ukraine-association-agreement-pifer.

Pöttering H.-G. (2009), www.euractiv.com/en/opinion/clinton-sees-us-eu-leading-world/article-180031 .

Remarks by President Obama to the Australian Parliament, 17.11.2011, White House, Office of the Press Secretary, www.whitehouse.gov/the-press-office/2011/11/17/remarks-president-obama-australian-parliament.

Remarks by President Obama to the People of Estonia, 3.09.2014, White House, Office of the Press Secretary, www.whitehouse.gov./the-press-office/2014/09/03/remarks-president-obama-people-estonia.

Rees W. (2011), The US - EU Security Relationship. The tension between a European and a Global Agenda, Basingstoke.

Rice S., „The Daily Telegraph”, 17.07.2008, www.telegraph.co.uk/news/worldnews/barackobama/ 2435862/No-free-ride-for-Europe-says-top-Barack-Obama-aide.html.

Riester J. (2009), Waiting for September: German-American Relations between Elections, AICGS. nr 30, June.

Stoltenberg J. (2014), NATO Rosji się nie boi, „Gazeta Wyborcza”, 6.10.

Testimony of Mr Edward Lucas, 8.07.2014, www.foreign.senate.gov/imo/media/doc/Lucas_Testimony1.pdf.

„USA Today”, 2 III 2014, http://www.usatoday.com/story/theoval/2014/03/02/obama-russia-putin-ukraine-crimea/5944265/.

\section{Streszczenie}

Europa/Unia Europejska, dysponując niekwestionowanymi atutami, powinna też być aktywnym i skutecznym graczem na arenie międzynarodowej. Takie były oczekiwania Stanów Zjednoczonych, formułowane zwłaszcza przez administrację Baracka Obamy. Jednak z amerykańskiej perspektywy Europa nie sprawdziła się jako ważny aktor na scenie międzynarodowej, zaangażowany w rozwiązywanie problemów globalnych i gotowy brać większą odpowiedzialność za bieg spraw w świecie. Ta inercja Unii Europejskiej powodowała, że nastappiła marginalizacja Europy w polityce amerykańskiej, czego wyrazem był, pivot to the Pacific Rim”. Dopiero wydarzenia na Ukrainie, będące efektem imperialnych tendencji w działaniach Rosji, spowodo- 
wały większą aktywność i koherentność polityki amerykańskiej i europejskiej, prowadząc też do wzmocnienia układu transatlantyckiego.

Slowa kluczowe: stosunki transatlantyckie, Ukraina, współpraca, konflikt

\section{Ukraine and transatlantic relations}

\section{Summary}

Europe/the European Union, with its obvious trump cards, should be an active and efficient player on the international arena. Such are the expectations of the United States, formulated especially by the administration of Barack Obama. However, from the American perspective, the EU has not proved successful as an important international actor, engaged in resolving global problems and prepared to assume greater responsibility for the course of events in the world. This inertia of the EU resulted in the marginalisation of Europe in American politics, as manifested by the latter's pivot to the Pacific Rim. It was only after the developments in the Ukraine, which resulted from Russia's imperial tendencies, that a greater activity and coherence in American and European politics was triggered, having a positive influence also on transatlantic relations.

Key words: transatlantic relations, Ukraine, cooperation, conflict 
